\title{
Assessment of Efficiency of Realization of Paternalistic Policy of Industrial Enterprises Development
}

Doi:10.5901/mjss.2014.v5n12p9

\author{
Bagautdinova N. ${ }^{a}$ \\ Sarkin $A^{b}$ \\ Averyanov B.c
}

Novenkova Ad1

Arzhantseva N.e

a bcdeKazan Federal University, Kazan, 420008, Russia

1Email : followaida@gmail.com

Abstract

The article describes the methodology of adapting of $M$. Porter's model of influence of five market forces to the conditions of new paternalistic economy considering the priority impact of procedures of the state stimulation and administration of activity of the industrial enterprises. The model is applied to the processes of diagnosing of the current state and perspectives of future development, as well as planning, organization and regulation of processes of the economic entity of the industrial sphere within formation of strategy of its constant growth. In the article the system of indicators of the assessment of productivity and efficiency of activity of the industrial enterprise (association) in the conditions of new paternalistic economy is created. It is structured in terms of elements of the system of balanced indicators and includes the corresponding complexes of private and group indicators.

Keywords: Paternalistic state, paternalistic strategy of development of the industry, M. Porter's model of influence of five market forces, state regulation of economy, indicators of productivity and efficiency of activity of the industrial enterprise, system of the balanced indicators.

\section{Introduction}

The analysis of alternative approaches to the definition of the ratio of the role of state and market regulators in providing a sustainable development of the Russian economy allows to draw a conclusion on recognition by the vast majority of scientists of the leading role of state in realization of progressive dynamics of economic and social indicators [10; 11]. At the same time the treatment of state functions according to the principles of welfare theory defining their contents proceeding from the analysis of "market failures", doesn't seem to be workable as it is based on recognition of absolute rationality of behavior of economic agents which contradicts the reality. In this respect it seems reasonable to develop a methodological base which considers a rational choice as a standard ideal, but at the same time disproves it as the initial postulate. It will allow to prove the concept of new paternalistic economy which denies paternalism as the product of traditional society coordinated with its main characteristics (rigid hierarchy, the importance of a personal contact, etc.), and recognizes paternalistic institutes as an integral part of the institutional environment of a modern state providing detailed and target guardianship over society as a condition of development of the latter according to the demands of post-industrial society. [9]

The significant role in understanding of the concept of paternalism play the works of representatives of traditional institutionalism (T.Veblen, J. Kommons, U. Mitchell, etc.) and neoinstitutionalism (R. Kouz, D. Nort, O. Williamson, etc.). Essential contribution to the development of the theory of strategic management of enterprises and complexes with account to the factors of environment is made in the works of foreign researchers, among which M. Albert, I. Ansoff, L.Vodacek, V.E.Deming, A.S.Konson, M.Kh.Meskon, R. Mason, M. Porter, A.D.Strikland, B. Twiss, F.Khedouri, etc. 


\section{Methodology}

The development of industrial enterprises in the conditions of new paternalistic economy is realized in the conditions under which the influence of five market forces described by M. Porter is substantially modified with the account to dual presence of the state in economy, performing the roles of the owner of industrial enterprises and of the national regulator of institutional environment at the same time. As a result, ensuring competitiveness of industrial economic entities in the long-term prospect presupposes the research of the environment of functioning and development of the enterprise within the system of five market forces adapted to the conditions of new paternalistic economy, the major feature of which is growth of transaction expenses caused by the need of production both of private and public benefits for sustainable vital activity of the industrial enterprise. The structure and the course of influence of Porter's five market forces are presented in fig. 1.

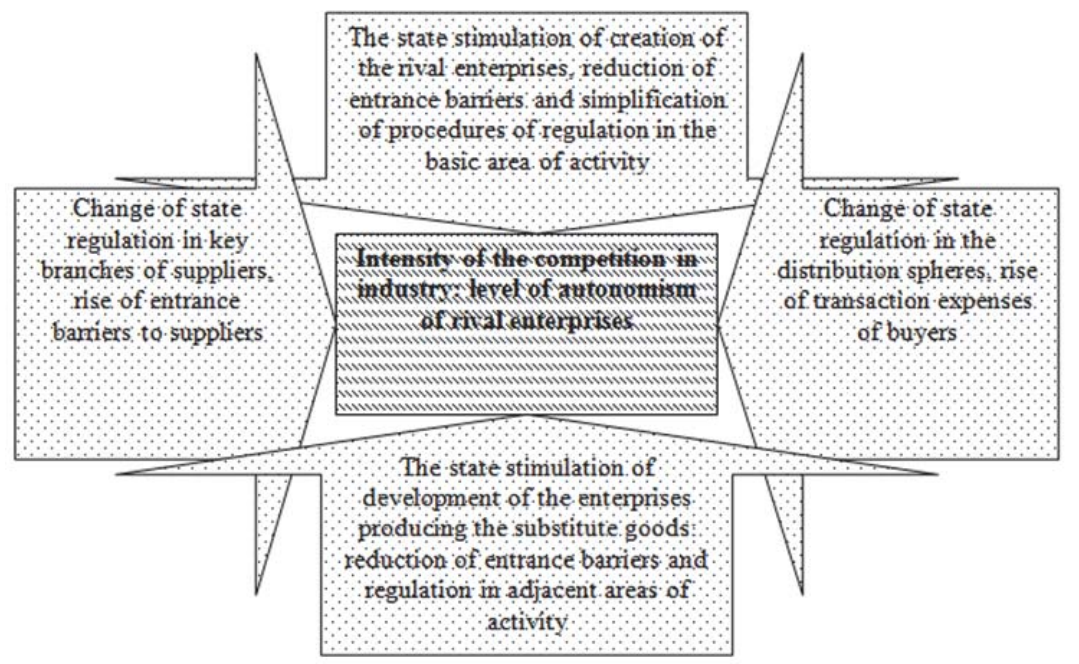

Fig. 1. Porter's model of five market forces adapted to the conditions of new paternalistic economy

As is seen from the figure, in the concept of five market forces influencing the industrial enterprise in the conditions of new paternalistic economy, the major factor defining the intensity of competition, is the level of autonomism of competing economic entities which allows to lower cumulative expenses of the industrial enterprise due to the reduction of transaction expenses. Unlike traditional market economy within which the use of outsourcing operations, as a rule, leads to decrease in cumulative expenses, in the new paternalistic economy the transfer of operations for outsourcing causes outrunning (in comparison to the rates of decrease of direct expenses) growth of transaction expenses reducing the effectiveness of the division of labor as a result of which in the economic system of the considered type large industrial holdings incorporating the production of traditionally public, mixed and private benefits, prevail, and the production of public benefits (in a format of providing law and order, providing educational and medical services, etc.) is realized only concerning internal and external contractors of the industrial enterprise. In the conditions of new paternalistic economy the influence of potential competitors intensifies at the change of processes of state regulation which form institutional conditions for entering and functioning in the basic area of activity of the industrial enterprise realized either in a format of simplification of procedures of control and administration (indirect impact on development of new enterprises), or in a form of stimulation of the development of new industrial enterprises (direct impact on development of new enterprises) [5].

The result of the listed types of influence having the most essential impact on the dynamics of creation and development of industrial enterprises in accordance with the expert assessment carried out in the research, is the increase of impact of threat of nascence of new competitors on the market.

The change of the market power of buyers of the industrial enterprise in the paradigm of new paternalistic economy is the consequence of redesigning of the processes of state regulation in the activity of economic subjects in the 
sphere of distribution that causes growth of transaction expenses of buyers, defining decrease in their number and interdependent increase of market power of clients of industrial economic entity [9]. Similarly, the market power of suppliers can strengthen on condition of complicacy of procedures of state administration of the activity of a given type of contractors of the industrial enterprise which causes growth of transaction expenses of suppliers the result of which is the decrease in their number, owing to the processes of merges and take-overs, or reduction of the amounts of delivery $[6,7]$.

Change of conditions of administration as an instrument of indirect impact on the activity of economic entities in adjacent areas of activity, together with the realization of direct measures for stimulation of development of industrial enterprises producing substitute goods, causes an increase of threat of appearing of such alternatives which, in their turn, change the sphere of influence of market forces and intensity of the competition for the industrial enterprise.

Thus, in the process of forming a strategy for a sustainable development of an industrial economic entity in the conditions of new paternalistic economy it is necessary to consider possible changes of direct and institutional regulation influencing the prospects of functioning and development of the industrial enterprise in strategic prospect by means of changing of the area of market forces.

\section{Results}

The conducted research showed that in the conditions of new paternalistic economy the stable tendency to integration of industrial economic entities is observed. This is the tendency for formation of associations which include the organizations duplicating functions of the state on production of public benefits for contractors of the created association of enterprises the kernel of which is the industrial enterprise.

This circumstance is confirmed by the significant positive correlation between the volume of annual revenue of the industrial enterprise, and the level of services delivered to the contractors related to the sphere of public benefits [2] (the assent of this parameter was carried out by means of defining the relation of aggregate cost of public benefits received by contractors of the industrial enterprise with the involvement of their own resources of the enterprise or its subdivisions, the affiliated or related organizations, to the total overhead expenses of the industrial enterprise during a certain period of time; with the rating scale $-0 \div 1$ ) which constitutes $r=0,6919$ for the selection of fifteen enterprises of the Republic of Tatarstan considered in the research.

Formally, this dependence represents a polynomial one in which the share of the benefits provided by the industrial enterprise to the contractors which is treated as public in the traditional market economy, is a dependent variable, and the revenue of the industrial enterprise (association) - an independent variable. The analysis of methodological approaches to the creation of the system of indicators of the efficiency and productivity of activity of the industrial enterprise (association) revealed that it is reasonable to use the set of criteria including indicators of financial activity, indicators of relations with clients, characteristics of internal business processes and the condition of the system of training and development as a frame of systematization of these indicators created within the system of balanced indicators [1;3]. It was also defined that the complex assessment of the activity of a domestic industrial enterprise presupposes the accounting of basic and special indicators (the latter reflect features of functioning and development of the economic entity in the conditions of new paternalistic economy) on the one hand, and the creation of three-level system of the indicators including private, group and integrated indicators on the other [4; 8]. The system of indicators of assessment of efficiency and productivity of activity of the industrial enterprise in the conditions of new paternalistic economy which is created subject to comparability of individual indicators, is presented in table 1. As is seen from the provided data, the indicators which characterize the tendencies of development inherent in new paternalistic economy are assumed as prioritized in the case of research of non-financial criteria of activity of the industrial enterprise, whereas the indicators defining a market trend of development of the economic entity play a big role in the assessment of basic indicators. 
Table 1:The system of indicators of an assessment of efficiency and productivity of activity of the industrial enterprise in the conditions of new paternalistic economy

\begin{tabular}{|c|c|c|c|c|}
\hline Elements & $\begin{array}{c}\text { Type of } \\
\text { indicators }\end{array}$ & Individual criteria & Group criteria ${ }^{1}$ & $\begin{array}{c}\text { Overall } \\
\text { performance }{ }^{2}\end{array}$ \\
\hline 1 & 2 & 3 & 4 & 5 \\
\hline 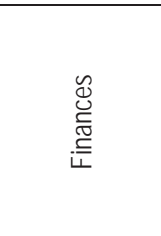 & Basic & \begin{tabular}{|l|} 
1. Growth rate of sales profitability \\
2. Growth rate of labor productivity, a \\
share \\
3. Growth rate of the enterprise market \\
co st \\
4. Growth rate of investment \\
profitability
\end{tabular} & $\begin{array}{l}\text { Fgb, defined as the weighted average of } \\
\text { individual criteria (weight of the importance of } \\
\text { indicators is defined by specific features of the } \\
\text { enterprise) }\end{array}$ & $\begin{array}{c}\mathrm{OF}=0,6 \mathrm{~F}_{\mathrm{gb}}+ \\
\quad+0,4 \mathrm{~F}_{\mathrm{gs}}\end{array}$ \\
\hline & Special & $\begin{array}{l}\text { 1. Growth rate of government order in } \\
\text { the sales pattern } \\
\text { 2. Growth rate of output capital ratio of } \\
\text { the resources attracted for ensuring } \\
\text { development within state programs } \\
\text { 3. Growth rate of profitability of } \\
\text { execution of the state order }\end{array}$ & $\begin{array}{l}\text { Fgs, defined as a chronological average of } \\
\text { individual criteria }\end{array}$ & \\
\hline \multirow{2}{*}{ 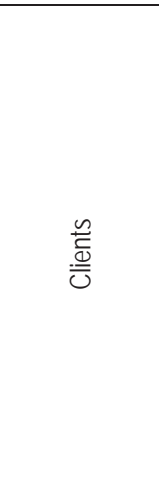 } & Basic & $\begin{array}{l}\text { 1. Growth rate of the market share, a } \\
\text { share } \\
\text { 2. Growth rate of an index of } \\
\text { consumers satisfaction, a share } \\
\text { 3. Growth of expenses on consumer } \\
\text { service, a share } \\
\text { 4. Growth rate of the number of claims, } \\
\text { a share }\end{array}$ & $\begin{array}{l}\text { Cgb, defined as the weighted average of } \\
\text { individual criteria (weight of the importance of } \\
\text { indicators is defined by the specific features of } \\
\text { the enterprise) }\end{array}$ & \multirow{2}{*}{$\begin{array}{c}\mathrm{OC}=0,35 \mathrm{C}_{\mathrm{gb}}+ \\
0,65 \mathrm{C}_{\mathrm{gs}}\end{array}$} \\
\hline & Special & $\begin{array}{l}\text { 1. Growth rate of deliveries per one } \\
\text { consumer, a share } \\
\text { 2. Growth rate of the number of tenders } \\
\text { for placement of the state order, a } \\
\text { share } \\
\text { 3. Growth rate of successful attempts } \\
\text { of lobbying, a share }\end{array}$ & $\begin{array}{l}\text { Cgs, defined as a chronological average of } \\
\text { individual criteria }\end{array}$ & \\
\hline $\begin{array}{l}\text { Education and } \\
\text { development }\end{array}$ & Basic & $\begin{array}{l}\text { 1. Growth rate of research and } \\
\text { development investment, a share } \\
\text { 2. Growth rate of personnel } \\
\text { development investment, a share } \\
\text { 3. Growth rate of an index of worker } \\
\text { satisfaction, a share } \\
\text { 4. Growth rate of reliability of } \\
\text { organizational contacts, a share } \\
\text { 5. Growth rate of a share of new } \\
\text { production proceeds in corporate } \\
\text { revenue structure }\end{array}$ & $\begin{array}{l}E D_{\mathrm{gb}} \text {, defined as the weighted average of } \\
\text { individual criteria (weight of the importance of } \\
\text { indicators is defined by the specific features of } \\
\text { the enterprise) }\end{array}$ & $\begin{array}{c}\mathrm{OED}=0,4 \mathrm{ED}_{\mathrm{gb}}+ \\
0,60 \mathrm{ED}_{\mathrm{gs}}\end{array}$ \\
\hline
\end{tabular}

\footnotetext{
${ }^{1}$ While defining the group criteria the calculations are conducted preserving the sign characterizing the tendency of the change of the individual indicator

${ }^{2}$ Specific weight of the importance of basic and special criteria in the overall performance was determined by the method of expert evaluations with the usage of PATTERN technology
} 


\begin{tabular}{|l|l|l|l|}
\hline & $\begin{array}{l}\text { 1. Growth rate of the attracted } \\
\text { resources of the state and state } \\
\text { companies for research and } \\
\text { development, a share } \\
\text { 2. Growth rate of the number of } \\
\text { prioritized state projects in the } \\
\text { realization of which the enterprise takes } \\
\text { part, a share } \\
\text { 3. Growth rate of profitability of the use } \\
\text { of public information resources, a share } \\
\text { 4. Growth rate of expenses on } \\
\text { controlling the processes inherent in } \\
\text { state regulation of the enterprise } \\
\text { indicators is defined by the specific features of } \\
\text { activity, a share }\end{array}$ & \\
\hline
\end{tabular}

Interviews with the experts estimating the specific weight of group indicators within the formation of integrated criterion of assessment showed that this tendency arises as the result of importance of diversification of operating conditions of particular economic entities in conditions of new paternalistic economy which reveals itself firstly in a format of non-financial indicators. Thus, widespread approach to the assessment of productivity and efficiency of industrial enterprises only from the point of view of dynamics of financial performance in conditions of new paternalistic economy leads to essential distortion of current state and prospects of development of industrial economic entities.

\section{Conclusions}

Thus, the formation of the model of new paternalism and realization of the measures of regulating influence on the part of the state taking into account the instability of preferences and uncertainty of environment is sure to provide the improvement of quality of choice and efficiency of administrative decisions on condition that these measures are developed according to the principles of the new model regarding industrial enterprises (associations). The realization of the offered methodological approach and the formulated methodical recommendations will provide progressive dynamics of economic and social indicators of the state of the industrial complex and the Russian economy in general.

\section{References}

Ampuero M., Goranson J., Scott J. Solving the Measurement Puzzle: How EVA and the Balanced Scorecard Fit Together // The Cap Gemini Ernst \& Young Center for Business Innovation. Issue 2 "Measuring Business Performance". - 1998. - P. 45-52.

Shaidullin R.N., Ulesov D.V., Shigabieva A.M. and Safiullin L.N. Innovative Infrastructure in Post-Industrial Society/l World Applied Sciences Journal, 27(13), 2013, pp. 180-183.

Combining EVA with the Balanced Scorecard to improve strategic focus and alignment: 2GC Discussion Paper. - UK: 2GC Active Management, 2001.

Kaplan R.S., Norton D.P. The Strategy-Focused Organization: How Balanced Scorecard Companies Thrive in the New Business Environment. - Boston (Ma., USA): Harvard Business School Press, 2001.

Fakhrutdinova, E., Safina, L., Shigapova, D., Yagudin, R. Legislative provision of the quality of working life in Russia// World Applied Sciences Journal.Volume 27, Issue 13, 2013, Pages 92-96.

Kirshin I.A., Datsyk A.A., Titov A.V. Forecasting the Dynamics of an Innovative Cycle. - World Applied Sciences Journal (Economics, Management and Finance). - 2013. - №27. - P. 197 - 201.

Glebova I.S., Sadyrtdinov R. and Rodnyansky D. Impact Analysis of Investment Attractiveness of the Republic of Tatarstan on Fixed Investments of its Leading Companies // World Applied Sciences Journal 26 (7): 911-916, 2013.

Kirshin I.A. Modeling the long-term trend of accumulation of knowledge. Life Science Journal 2014; 11(6s): $482-486$.

Mitchell G. Libertarian Paternalism Is an Oxymoron // Northwestern University Law Review. 2005. Vol. 99. No. 3. P. $1245-1277$.

Gainova R.A., Shaidullin R.N., Safiullin L.N. and Maratkanova E.M. Infrastructural Component in Maintenance of Competitiveness of Region// World Applied Sciences Journal, 27(13), 2013, pp. 97-101.

Ulesov D.V., Murtazina G., Safiullin L.N. and Saipullaev U.A. Special Aspects of Development of Business in the Knowledge-Based Economy //World Applied Sciences Journal, 27(13), 2013, pp. 189-192.

Safiullin L.N., Shaidullin R.N., Ulesov D.N., Shigabieva A.M. Essential features of small and medium business. Life Science Journal 2014; $11(6 s): 392-395$.

Paternalism // Stanford Encyclopedia of Philosophy. 2009 Edition. (http://plato.stanford.edu/archives/sum2009/entries/paternalism/\#1).

Rizzo M. J., Whitman D. G. The Knowledge Problem of the New Paternalism // Brigham Young University Law Review. 2009. No. 4. P. 905-968. 
Sugden R. Why Incoherent Preferences Do Not Justify Paternalism // Constitutional Political Economy. 2008. Vol. 19. No. 3. P. 226-248. 